\title{
Effect of mixotrophic growth on the ultrastructure and fatty acid composition of the diatom Synedra acus from Lake Baikal
}

Sergey M Shishlyannikov*, Igor V Klimenkov, Yekaterina D Bedoshvili, Ivan S Mikhailov and Alexander G Gorshkov

\begin{abstract}
Background: Interest in studies concerning the effect of organic carbon sources on the growth of diatoms is largely aimed at subsequent physiological changes occurring in their cells. There are no data on structural changes in the cytoplasm and their relationship with changes in the composition of fatty acids in the course of mixotrophic culturing of freshwater diatoms. To elucidate the role of lipids in the growth of diatom cells in autotrophic and mixotrophic cultures, it is necessary to obtain information on the distribution of fatty acids among intracellular compartments and on possible ultrastructural changes in the cells.
\end{abstract}

Results: In this study, the results demonstrated that Synedra acus cells cultured in the presence of $80 \mathrm{mM}$ glycerol contained lipid bodies of increased size, while cells from cultures supplemented with $40 \mathrm{mM}$ glucose accumulated polysaccharide (chrysolaminarin) granules. An increase in the relative amounts of palmitic and stearic acids was revealed at the exponential growth phase of S. acus in the medium with $80 \mathrm{mM}$ glycerol, which was indicative of the accumulation of fatty acids contained in triacylglycerols.

Conclusions: Synedra acus subsp. radians have an ability to proliferate in the presence of high concentrations of organic substances and their transport into cells is evidence for its high adaptation potential, which, along with other factors, accounts for the dominance of this diatom in the spring-summer plankton of the oligotrophic Lake Baikal.

Keywords: Synedra acus, Lake Baikal, Ultrastructure, Lipid bodies, GC-MS, Fatty acids

\section{Background}

Diatoms are autotrophic microalgae that, under certain conditions, can utilize organic carbon sources as nutrients [1-4]. As a rule, these substances are used to store energy as well as to satisfy metabolic needs for cell growth. For example, some species of microalgae assimilate up to $85 \%$ of available glucose in the form of reserve polysaccharides [5] whereas other species (e.g. Prymnesium parvum and Dunaliella tertiolecta) cannot assimilate glucose even though they have the enzyme systems necessary for their metabolism [6]. Glycerol contained in the medium can also be utilized by some microalgae, which provides for an increase in their growth rate [3] and induces certain biochemical [7] and structural changes in the cell, particularly in the morphology of chloroplasts [8].

\footnotetext{
* Correspondence: sershilin@gmail.com

Limnological Institute, Siberian Branch, Russian Academy of Sciences, 3 , Ulan-Batorskaya, St, P.O. Box 278, Irkutsk 664033, Russia
}

When nutrient supply is sufficient and environmental conditions are favorable, phytoplankton develops at a high rate, and the greater part of intracellular carbon is in the form of proteins. Under stressful conditions, such as nutrient deficiency (silicon, phosphorus, nitrogen, etc.) [9-11] or insufficient amount of sunlight [12], diatoms begin to store lipids and polysaccharides (in particular, chrysolaminarin) as energy reserve molecules. In the norm, fatty acids in microalgae are utilized mainly for the synthesis of membrane lipids. Under stress, lipid metabolism shifts toward the production of triacylglycerols and enrichment of lipid bodies in the cytoplasm [13].

As shown in previous experiments with diatom cultures, their cells accumulate triacylglycerols as the composition of the medium changes and the age of the culture increases $[14,15]$, with the resulting increase in the amount of lipids in the cell being accompanied by changes in the composition (ratio) of fatty acids [16-18]. Data on changes in the composition of fatty acids depending on environmental 
factors provide a basis for the search of new biological indicators characterizing the state of aquatic ecosystems under conditions of climate-dependent changes in the temperature of water bodies and their increasing trophicity resulting from the impact of human activities. Moreover, analysis of the effect of stress factors on the development of diatoms may provide the possibility of optimizing biotechnology of their culturing in order to obtain cell biomass with the desirable composition of lowmolecular-weight compounds, fatty acids in particular.

Diatoms, green and red algae are natural producers of value-added bioactive compounds, such as PolyUnsaturated Fatty Acids (PUFAs). Some essential PUFAs including EPA (eicosapentaenoic acid, $\omega-3$, C20:5), DHA (docosahexaenoic acid, DHA, $\omega-3, \mathrm{C} 22: 6$ ), and AA (arachidonic acid, $\omega-3$, C20:4) have critical physiological functions, e.g., preventing high cholesterol, myocardial infarction and improving high blood pressure, etc. Therefore, PUFAs have attracted a great attention due to their beneficial effects on human health [19]. Microalgae have potential for numerous commercial applications, among them the production of PUFAs [20]. Diatoms normally contain significant amount of EPA and lower levels of DHA [21-23]. Red algae also synthesize large amounts of EPA accompanied with AA [24]. EPA and DHA are typically absent in green algae [25] but these algae contain, in generally, primarily C16 and C18 PUFAs [26,27].

Interest in studies on the effect of organic carbon sources on the growth of diatoms is largely aimed at subsequent physiological changes occurring in their cells. A fairly detailed analysis has been made of various factors having an effect on the ultrastructure of marine and freshwater diatoms cultured under autotrophic, mixotrophic, and heterotrophic conditions [8,28-32]. On the other hand, there are no data on structural changes in the cytoplasm and their relationship with changes in the composition of fatty acids in the course of mixotrophic culturing of freshwater diatoms. To elucidate the role of lipids in the growth of diatom cells in autotrophic and mixotrophic cultures (supplemented with organic carbon sources), it is necessary to obtain information on the distribution of fatty acids among intracellular compartments and on possible ultrastructural changes in the cells.

Synedra acus subsp. radians (Kütz.) Skabitsch, one of dominant species in the phytoplankton of oligotrophic Lake Baikal, has been the object of intensive research on morphogenesis of frustules [33] as well as of molecular [34-36], cytological [37], and genomic studies [38]. As shown previously, this diatom is a potential source of PUFSa, mainly of EPA [39].

The purpose of this study was to analyze changes in the morphology and fatty acid composition of S. acus cells cultured in the presence of glucose and glycerol as organic carbon sources.

\section{Results}

In preliminary experiments, the maximum concentrations of organic carbon sources in the medium that did not result in a reduced rate of cell divisions or gradual cell death in $S$. acus culture were estimated at $40 \mathrm{mM}$ for glucose and $80 \mathrm{mM}$ for glycerol (Figures 1 and 2).

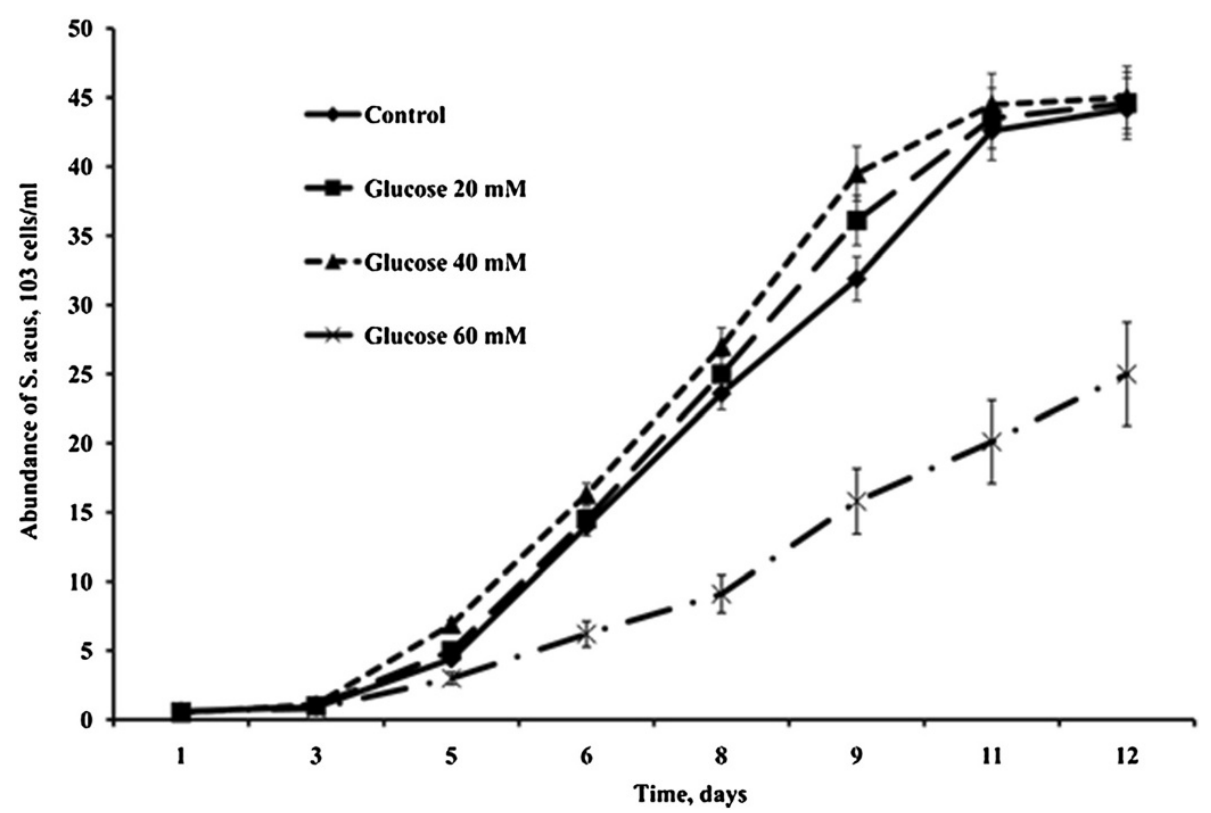

Figure 1 Dynamics of S. acus abundance in autotrophic and mixotrophic cultures with different concentrations of glucose. 


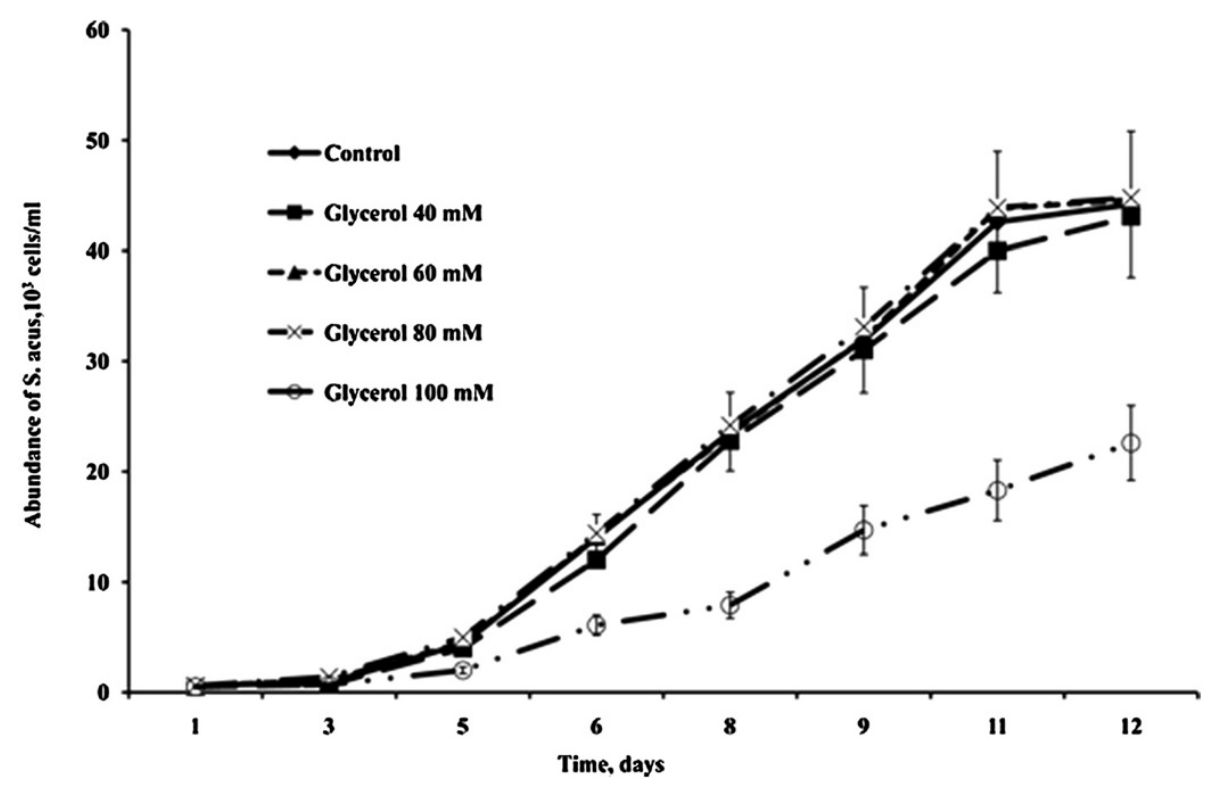

Figure 2 Dynamics of S. acus abundance in autotrophic and mixotrophic cultures with different concentrations of glycerol.

Therefore, it is these concentrations that were used in subsequent mixotrophic cultures.

According to the results of TEM, S. acus cells in autotrophic culture (Figure 3B) formed vacuoles (up to $1.0 \mu \mathrm{m}$ ) with homogeneous electron-dense contents, which could be located either at the periphery or in the center of the cell (Figure 3E). These vacuoles in preparations stained with Nile red were bright orange (Figure $3 \mathrm{~A}$ ), which was evidence for the lipid nature of their contents [40]. Such intracellular lipid bodies were also found in cells cultured under mixotrophic conditions (with glycerol or glucose). It should be noted, however, that the size of lipid bodies in cells from cultures with glycerol was greater than in cells from either autotrophic (control) or glucosecontaining cultures, reaching $2.5 \mu \mathrm{m}$ (Figure $3 \mathrm{C}$ and $3 \mathrm{~F}$ ). Such glycerol-dependent accumulation of lipids in the cytoplasm of diatoms was observed already at the phase of their exponential growth. Further enlargement of lipid inclusions at the stationary growth phase resulted in a increase in the overall cell volume, which was usually accompanied by deformation of the cell wall in the girdle zone (Figure 3F). At the stage of frustule formation, cells cultured in the presence of glucose contained a different kind of vacuoles $(0.5-0.7 \mu \mathrm{m})$, which had heterogeneous granular and small-grained contents $(10-20 \mathrm{~nm}$, Figure 3D), and also included more electron-dense granules of a larger size $(20-40 \mathrm{~nm}$, Figure 3D). Such structures were not revealed in the cells cultured in autotrophic conditions and with glycerol. The characteristic structure of these organelles [41] could be regarded as evidence for the accumulation of polysaccharides (in particular, chrysolaminarin) in the cells.
Analysis of S. acus cell lipids was performed by means of their acid hydrolysis followed by gas chromatography of the extracted fraction of fatty acid methyl esters. It was found that the qualitative composition of fatty acids remained basically unchanged in the course of culture growth (Table 1). Thus, the group of dominant fatty acids at the exponential growth phase included myristic (C14:0), palmitic (C16:0), palmitoleic (C16:1), hexadecatrienic (C16:3) stearic (C18:0), and eicosapentaenoic (C20:5) acids, and that at the stationary growth phase, myristic, palmitic, palmitoleic, and eicosapentaenoic acids. Such composition of fatty acids is typical for hydrolysates of diatom lipids [21,22].

As follows from Table 1, $\Sigma$ SFA $/ \Sigma$ (MUFA + PUFA) ratios in cell lipids markedly differed between cells cultured under photoautotrophic and mixotrophic conditions at the exponential phase. For example, palmitic and stearic acids dominated in the fatty acid spectrum of $S$. acus cells cultured with $80 \mathrm{mM}$ glycerol, indicating that these acids, contained in triacylglycerols, were accumulated in the lipid bodies.

Judging from the $\Sigma$ SFA $/ \Sigma($ MUFA + PUFA) ratios of fatty acids in lipid hydrolysates, the relative amount of saturated fatty acids in $S$. acus cells decreased at the stationary growth phase in autotrophic cultures and mixotrophic cultures with $80 \mathrm{mM}$ glycerol but remained unchanged in cultures with $40 \mathrm{mM}$ glucose (Table 1). The contents of monounsaturated fatty acids increased threefold at the stationary growth phase in both autotrophic and mixotrophic cultures with glucose or glycerol. The amount of PUFAs decreased in autotrophic cultures and mixotrophic cultures with $40 \mathrm{mM}$ glucose but changed only slightly in cultures with $80 \mathrm{mM}$ glycerol. 

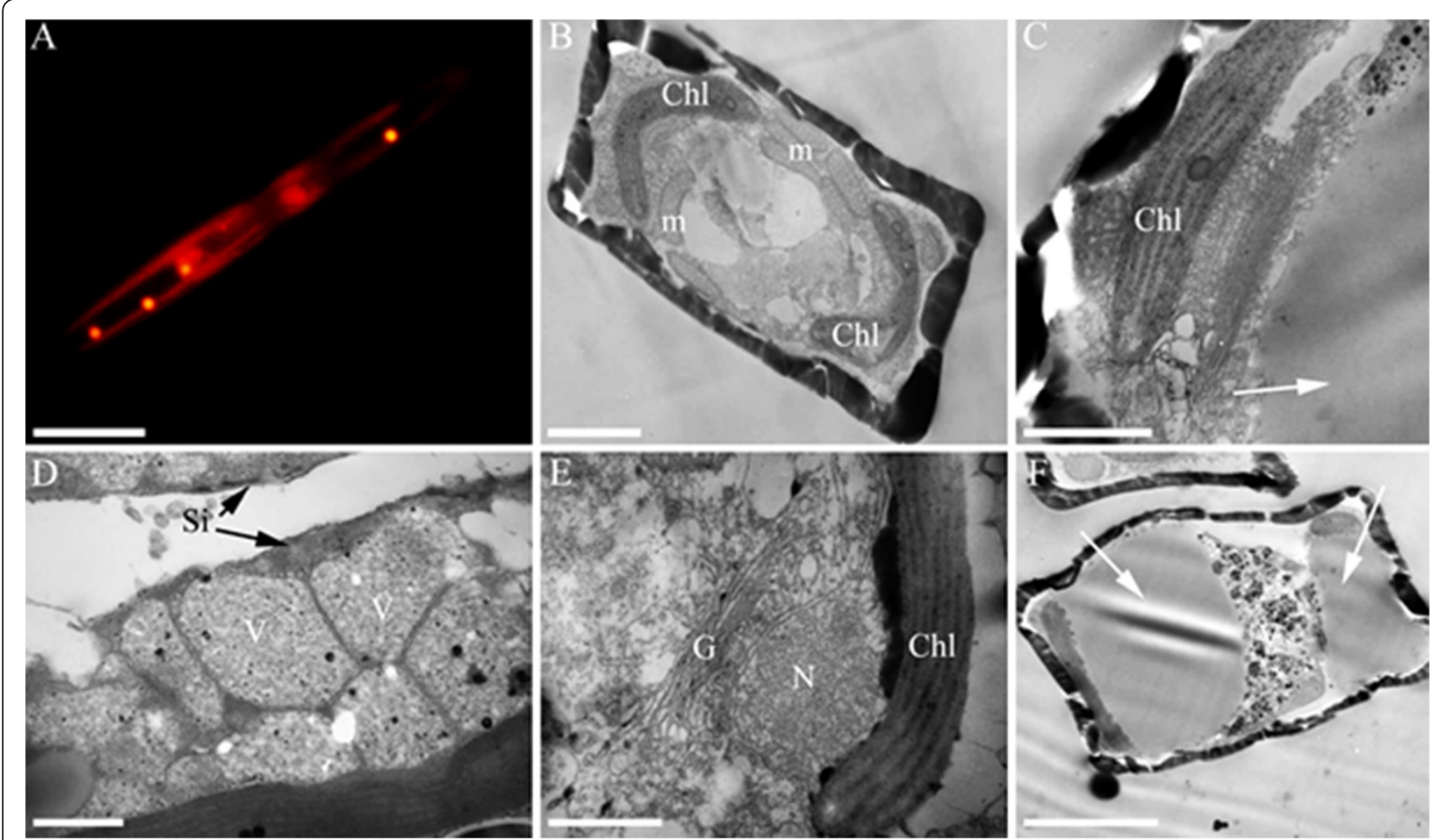

Figure 3 Fluorescence and transmission electron micrographs of Synedra acus cells. Yellow fluorescence of lipid bodies stained Nile Red dye and the red autofluorescence of chloroplasts (A), ultrastructural characteristics Synedra acus cells in autotrophic culture (B, E) and in mixotrophic cultures with glycerol (C, F) and glucose (D). Designations: Chl -chloroplast; V-vacuole with chrysolaminaran granules, $\mathrm{m}$ - mitochondria. $\mathrm{N}$ - nucleus. White arrows indicate lipid bodies. Scale bars: (A) - $10 \mu \mathrm{m},(\mathbf{C}, \mathbf{D}, \mathbf{E})-500 \mathrm{~nm},(\mathbf{B}, \mathbf{F})-2 \mu \mathrm{m}$.

Table 1 Fatty acid composition (\% of total fatty acid) in S. acus biomass from different types of cultures $(n=3)$

\begin{tabular}{|c|c|c|c|c|c|c|}
\hline \multirow[t]{2}{*}{ Fatty acid (FA) } & \multicolumn{2}{|c|}{ Autotrophic culture } & \multicolumn{2}{|c|}{$\begin{array}{l}\text { Mixotrophic culture } \\
\text { (40 mM glucose) }\end{array}$} & \multicolumn{2}{|c|}{$\begin{array}{l}\text { Mixotrophic culture } \\
\text { (80 mM glycerol) }\end{array}$} \\
\hline & $\begin{array}{l}\text { Exponential } \\
\text { phase }\end{array}$ & $\begin{array}{l}\text { Stationary } \\
\text { phase }\end{array}$ & $\begin{array}{l}\text { Exponential } \\
\text { phase }\end{array}$ & $\begin{array}{l}\text { Stationary } \\
\text { phase }\end{array}$ & $\begin{array}{l}\text { Exponential } \\
\text { phase }\end{array}$ & $\begin{array}{l}\text { Stationary } \\
\text { phase }\end{array}$ \\
\hline C14:0 & 12.0 & 12.9 & 13.6 & 17.9 & 9.8 & 10.7 \\
\hline C16:0 & 16.4 & 10.8 & 11.4 & 11.3 & 24.7 & 13.4 \\
\hline C18:0 & 16.9 & 3.1 & 10.3 & 3.7 & 27.1 & 4.6 \\
\hline C16:1 & 10.6 & 44.2 & 13.9 & 44.6 & 10.8 & 41.2 \\
\hline C18:1 & 0.0 & 0.9 & 0.0 & 1.4 & 0.0 & 0.7 \\
\hline $\mathrm{C} 22: 1$ & 0.0 & 0.0 & 1.1 & 0.0 & 0.0 & 0.0 \\
\hline C16:2 & 5.3 & 2.7 & 6.2 & 1.9 & 3.8 & 3.5 \\
\hline C16:3 & 17.2 & 5.1 & 18.6 & 2.3 & 9.9 & 7.0 \\
\hline C18:3 & 0.0 & 2.3 & 0.0 & 2.4 & 0.0 & 1.8 \\
\hline C20:5 & 19.0 & 16.8 & 21.1 & 13.2 & 11.3 & 16.0 \\
\hline C22:6 & 2.6 & 1.2 & 3.8 & 1.3 & 2.6 & 1.1 \\
\hline$\Sigma$ Saturated fatty acid (SFA) & 45.3 & 26.8 & 35.3 & 32.9 & 61.6 & 28.7 \\
\hline $\begin{array}{l}\sum \text { Monounsaturated fatty acid } \\
\text { (MUFA) }\end{array}$ & 10.6 & 45.1 & 15.0 & 46.0 & 10.8 & 41.9 \\
\hline $\begin{array}{l}\text { ¿ Polyunsaturated fatty acid } \\
\text { (PUFA) }\end{array}$ & 44.1 & 28.1 & 49.7 & 21.1 & 27.6 & 29.4 \\
\hline$\Sigma S F A / \Sigma(M U F A+P U F A)$ ratio & 0.8 & 0.3 & 0.5 & 0.5 & 1.6 & 0.4 \\
\hline
\end{tabular}




\section{Discussion}

The data presented above show that the fatty acid profile of lipids from diatom cells is subjected to changes, which apparently result from exposure to stress factors. One of such factors may be the addition of organic carbon sources (glucose or glycerol) to the culture medium.

At the stationary growth phase, the content of palmitoleic acid in S. acus culture has proved to increase, by more than $40 \%$ relative to the total amount of fatty acids (Table 1). This fatty acid is most prevalent in the composition of diatom lipids $[21,42,43]$. Fatty acid biosynthesis in all plastid-containing organisms is catalyzed by type II fatty acyl synthase [44]. Armbrust et al. described complete cycles of the biosynthesis of polyunsaturated fatty acids in the marine diatom Thalassiosira pseudonana [45]. Fatty acids synthesized in plastids are exported to the cytoplasm to be incorporated into intracellular lipids. It is known that diatom cells in cultures at the stationary growth phase experience a deficit of nutrients and begin to accumulate storage compounds such as lipids, inorganic ions and polysaccharides $[11,46]$. When the medium is supplemented with a certain source of carbon, diatoms can build up more biomass due to intensification of lipid biosynthesis [3,47]. Thus, the increase in the relative content of palmitoleic acid in S. acus cells may be regarded as evidence for its accumulation as a component of reserve triacylglycerols stored in lipid bodies. Palmitic, palmitoleic and stearic acids are known to prevail in reserve triacylglycerols accumulated by photosynthesizing cells $[18,48]$. In our experiments, the relative contents of stearic, palmitic, acids in the biomass of S. acus diatoms at the exponential growth phase were found to be higher in cultures with glycerol than in cultures with glucose or in the control (Table 1), which could be indicative of an increasing accumulation of lipids in $S$. acus cells.

In our experiments, the dominant PUFA was EPA at exponential growth phase (Table 1). The dietary uptake of EPA and DHA is very important in human health. High EPA productivity is typical for many diatoms, for example, Phaeodactylum tricornutum [23] Navicula saprophila and Nitzschia sp. [2]. Therefore, S. acus can be a preferable diatom that can be used as producer for " $\omega-3$ polyunsaturated fatty acids" (PUFAs) and the putative candidate for genetic engineering.

These biochemical data are supported by the results of microscopic analysis. TEM preparations of S. acus cells from cultures with glycerol at the exponential growth phase, when the cells experience increasing deficit in silica, clearly show that the size of lipid bodies in the cytoplasm increases, compared to the control, and that this increase continues at the stationary growth phase, resulting in the expansion of cell volume in the girdle zone (Figure 3F). This is evidence for the existence of a mechanism for transmembrane transport of glycerol into S. acus cells and its involvement in cell metabolism. It is known that glycerol not only has a structural function as a component of cell membrane lipids but also plays a role in energy metabolism (in the form of glycerol-3-phosphate) and regulation of glycerol transport and lipid metabolism, and transmembrane transport of small charged molecules [49].

Synedra acus cells cultured in the presence of glucose proved to form polysaccharide granules in the cytoplasm (Figure 3D), which were absent in cells from cultures with glycerol and control cultures. In previous microscopic and biochemical studies, the main polysaccharide stored in the vacuoles of marine and freshwater diatoms was identified as $\beta-1,3$-glucan, or chrysolaminarin $[41,50,51]$. This polysaccharide is metabolized during the dark period and thereby serves as an energy substrate for cell metabolism. As shown recently, the genome of the marine diatom Thalassiosira pseudonana contains genes coding for endoand exo-active $\beta$-1,3-glucanases involved in intracellular chrysolaminarin hydrolysis [45]. These data and the results of our experiments indicate that glucose molecules entering the cytoplasm of $S$. acus cells become involved in cell metabolism.

\section{Conclusions}

The results of this study do not provide unequivocal answers to the questions as to whether or how the processes of transport of silica and organic molecules through the diatom cell wall are coupled and to what extent they depend on each other. However, it is clear that $S$. acus cells under conditions of deficit in silica show the intake of molecules providing a source of energy (glucose or glycerol) from the ambient medium. The ability of this freshwater diatom to proliferate in the presence of high concentrations of organic substances and their transport into cells is evidence for its high adaptation potential, which, along with other factors, accounts for the dominance of Synedra acus subsp. radians in the spring-summer phytoplankton of oligotrophic Lake Baikal.

\section{Methods}

\section{Diatom culture}

The initial axenic $S$. acus culture maintained in the laboratory was isolated from a natural population sampled in Listvennichnyi Bay, Lake Baikal [52]. In this study, $S$. acus cells were cultured in 5-ml tubes and 1-1 Erlenmeyer flasks with DM medium [53] at $18^{\circ} \mathrm{C}$ and natural photoperiod. Test cultures were supplemented with different concentrations of glucose $(10,20,40$, or $60 \mathrm{mM})$ or glycerol $(10,40,60,80$, or $100 \mathrm{mM})$. Autotrophic cultures in DM medium without additives served as control. Cell counts in the cultures were taken daily during 12 days. All experiments were performed in triplicate. 


\section{Light microscopy}

Samples from the cultures were examined under an Axiostar Plus microscope (Carl Zeiss, Germany) at 1000x magnification. Microscopic images were made using an AxioCam I Cc1 digital camera with the AxioVision 4.7 program (Carl Zeiss, Germany).

\section{Fluorescence microscopy}

Samples for fluorescence microscopy were taken at the exponential and stationary phases of culture growth (1.5$2.0 \times 10^{4}$ and $3.5-4.0 \times 10^{4}$ cells $\mathrm{ml}^{-1}$, respectively). They were supplemented with $10 \mu \mathrm{l} \mathrm{of} \mathrm{a} 2 \mathrm{mg} \mathrm{ml}^{-1}$ stock solution of Nile red stain (Sigma, USA) in acetone, incubated for $5 \mathrm{~min}$, transferred onto a glass slide under a cover slip, and examined under an Axiovert 200 inverted microscope (Carl Zeiss, Germany) with an Osram HBO 50 W/AC mercury lamp. Microscopic images were made using a Penguin 600CL digital camera (Pixera Corp., USA) with the AxioSet program (Carl Zeiss, Germany).

\section{Transmission electron microscopy (TEM)}

Samples for TEM were taken at the exponential and stationary phases of culture growth $\left(1.5-2.0 \times 10^{4}\right.$ and $3.5-4.0 \times 10^{4}$ cells ml ${ }^{-1}$, respectively). They were concentrated on a polycarbonate membrane filter with a pore size of $5 \mu \mathrm{m}$ (Millipore, Ireland) placed in a Sartorius glassvacuum holder, $25 \mathrm{~mm}, 30 \mathrm{ml}$ (Germany) and fixed with glutaraldehyde (Sigma-Aldrich, USA) for $30 \mathrm{~min}$ and then with $\mathrm{OsO}_{4}$ (Merck, Germany) for 10 min (final concentrations $2.5 \%$ and $1 \%$, respectively). Thereafter, the cells were washed in three portions of DM medium, embedded in 1\% agar (Helicon, Russia), and dehydrated in an ascending alcohol series (10, 30, 50, 70, 80, and 96\%) followed by absolute alcohol and acetone dehydrated with calcined copper sulfate (3 min each). Dehydrated samples were impregnated with mixtures of Araldite 502 epoxy resin (SPI, USA) and acetone (1:2, 1:1, and 2:1, 6 hrs each) and with pure Araldite (12 hrs), transferred to a new portion of Araldite supplemented with DMP-30 accelerator (SPI; $250 \mu \mathrm{l}$ per $20 \mathrm{ml}$ of the resin), and polymerized in a thermostat at $60^{\circ} \mathrm{C}$ for 3 days. Ultrathin sections were made in an Ultracut R (Leica, Austria) with an ULTRA 35 diamond knife (Diatom, Switzerland), placed onto palladium grids, and contrasted with lead nitrate as described [54]. TEM analysis was performed using a Leo $906 \mathrm{E}$ microscope (Carl Zeiss, Germany) at an acceleration voltage of $80 \mathrm{kV}$. Microscopic images were made with a MegaView II camera (Carl Zeiss, Germany) and processed using the MegaVision program.

\section{Isolation of lipids}

Synedra acus cells from the culture were collected on a polycarbonate filter as described above, washed with sterile DM medium, transferred to 5-ml plastic tubes with screw caps, and treated with a 2:1 methanol-chloroform mixture ( $2 \mathrm{ml}$ per $50 \mathrm{mg}$ of cells) at $5^{\circ} \mathrm{C}$ for $12 \mathrm{hrs}$. For phase separation, the mixture was additionally supplemented with $1 \mathrm{ml}$ of chloroform and $1 \mathrm{ml}$ of water and incubated overnight at $5^{\circ} \mathrm{C}$. The chloroform phase was then collected, dried over anhydrous sodium sulfate, and the solvent was evaporated under argon.

\section{Preparation of fatty acid methyl esters}

Total lipids extracted from diatom cells $(10 \mathrm{mg})$ were suspended in $0.2 \mathrm{ml}$ of $2 \% \mathrm{H}_{2} \mathrm{SO}_{4}$ solution in methanol and incubated at $75^{\circ} \mathrm{C}$ for $1 \mathrm{hr}$ in a sealed tube. The mixture was then cooled, supplemented with several drops of water, and treated with three $0.2-\mathrm{ml}$ portions of n-hexane to extract fatty acid methyl esters. The extracts were pooled and evaporated under argon. Samples for subsequent analysis by means of Gas ChromatographyMass Spectrometry (GC-MS) were dissolved in $300 \mu \mathrm{l}$ of n-hexane.

\section{GC-MS analysis of fatty acid methyl esters}

Analysis was performed in an Agilent GC 6890 gas chromatography system with a DB-5MS capillary column (30 m $\times 0.25 \mathrm{~mm}, 250 \mu \mathrm{m}$ film thickness) coupled to an MSD 5973 mass spectrometer (Agilent Technologies, USA), under the following conditions: column heating from 160 to $300^{\circ} \mathrm{C}$ at $2^{\circ} \mathrm{C} / \mathrm{min}$, with the temperature maintained at $300^{\circ} \mathrm{C}$ for $20 \mathrm{~min}$; injector temperature $290^{\circ} \mathrm{C}$, quadruple temperature $150^{\circ} \mathrm{C}$; injected sample volume $2 \mu \mathrm{l}$. Peak detection was performed in the full scan mode in a mass range of 50 to 500 atomic mass units, at a scanning rate of $0.1 \mathrm{~s}$ and an ionization energy of $70 \mathrm{eV}$.

\section{Competing interests}

The authors declare that they have no competing interests.

\section{Authors' contributions}

SMS supervised the study, conceived the research, designed and performed data analyses, and drafted the manuscript. IVK performed the experiments and drafted the manuscript. AGG, EDB, ISM performed the experiments and analyzed the data. All authors read and approved the final manuscript.

\section{Acknowledgments}

The authors are thankful to Dr. E. Michaloudi from the editorial board of the journal and the anonymous reviewers for their useful comments. This work was financially supported by the Program of the Presidium of the Russian Academy of Sciences "Molecular and Cell Biology" (project no. 6.9).

Received: 26 September 2013 Accepted: 26 June 2014

Published: 4 August 2014

\section{References}

1. Lewin JC: Heterotrophy in Diatoms. J Gen Microbio/ 1953, 9:305-313.

2. Kitano M, Matsukawa R, Karube I: Changes in eicosapentaenoic acid content of Navicula saprophila, Rhodomonas salina and Nitzschia sp. under mixotrophic conditions. J Appl Phycol 1997, 9:559-563.

3. García MC, Fernández Sevilla JM, Acién Fernandez FG, Molina Grima E, García Camacho F: Mixotrophic growth of Phaeodactylum tricornutum on glycerol: growth rate and fatty acid profile. J Appl Phycol 2000, 12:239-248. 
4. Liu X, Duan S, Li A, Xu N, Cai Z, Hu Z: Effects of organic carbon sources on growth, photosynthesis, and respiration of Phaeodactylum tricornutum. J Appl Phycol 2009, 21:239-246.

5. Tanner W: The Chlorella hexose/H(+)-symporters. Int Rev Cytol 2000, 200:101-141.

6. Neilson $\mathrm{AH}$, Lewin RA: The uptake and utilization of organic carbon by algae: an essay in comparative biochemistry. Phycologia 1974, 13:227-264.

7. Lewitus AJ, Caron DA, Miller KR: Effects of light and glycerol on the organization of the photosynthetic apparatus in the facultative heterotroph Pyrenomonas salina (Cryptophyceae). J Phycol 1991, 27:578-587.

8. Liu XJ, Duan SS, Li AF, Sun KF: Effects of glycerol on the fluorescence spectra and chloroplast ultrastructure of Phaeodactylum tricornutum (Bacillariophyta). J Integr Plant Biol 2009, 51:272-278.

9. Roessler PG: Effects of silicon deficiency on lipid composition and metabolism in the diatom Cyclotella cryptica. J Phycol 1988, 24:394-400.

10. Reitan Kl, Rainuzzo JR, Olsen Y: Effect of nutrient limitation on fatty acid and lipid content of marine microalgae. J Phycol 1994, 30:972-979.

11. Granum E, Kirkvold S, Myklestad SM: Cellular and extracellular production of carbohydrates and amino acids by the marine diatom Skeletonema costatum: diel variations and effects of $\mathrm{N}$ depletion. Mar Ecol Prog Ser 2002, 242:83-94.

12. Terry KL, Hirata J, Laws EA: Light-limited growth of two strains of the marine diatom Phaeodactylum tricornutum: chemical composition, carbon partitioning and the diel periodicity of physiological processes. J Exp Mar Biol Ecol 1983, 68:209-227.

13. Cooksey KE, Guckert JB, Williams SA, Callis PR: Fluorometric determination of the neutral lipid content of microalgal cells using Nile Red. J Microbio/ Methods 1987, 6:333-345.

14. Hu Q, Sommerfeld M, Jarvis E, Ghirardi M, Posewitz M, Seibert M, Darzins A Microalgal triacylglycerols as feedstocks for biofuel production: perspectives and advances. Plant J 2008, 54:621-639.

15. Yu ET, Zendejas FJ, Lane PD, Gaucher S, Simmons BA, Lane TW: Triacylglycerol accumulation and profiling in the model diatoms Thalassiosira pseudonana and Phaeodactylum tricornutum (Baccilariophyceae) during starvation. J App/ Phycol 2009, 21:669-681.

16. Ackman RG, Jangaard PM, Hoyle RJ, Brockerhoff $\mathrm{H}$ : Origin of marine fatty acids. I. Analyses of fatty acids produced by the diatom Skeletonema costatum. J Fish Res Board Can 1964, 21:747-756.

17. Opute Fl: Studies on fat accumulation in Nitzschia palea Kutz. Ann Bot 1974, 38:889-902

18. Fisher NS, Schwarzenbach RP: Fatty acid dynamics in Thalassiosira pseudonana (Bacillariophyceae): implications for physiological ecology. J Phycol 1978, 14:143-150.

19. Nagao K, Yanagita T: Conjugated fatty acids in food and their health benefits. J Biosci Bioeng 2005, 100:152-157.

20. Khozin-Goldberg I, Iskandarov U, Cohen Z: LC-PUFA from photosynthetic microalgae: occurrence, biosynthesis, and prospects in biotechnology. Appl Microbiol Biotechnol 2011, 91:905-915.

21. Kates M, Volcani BE: Lipid components of diatoms. Biochim Biophys Acta 1966, 116:264-278

22. Arao T, Kawaguchi A, Yamada M: Positional distribution of fatty acids in lipids of the marine diatom Phaeodactylum trikornutum. Phytochemistry 1987, 26:2573-2576.

23. Hamilton ML, Haslam RP, Napier JA, Sayanova O: Metabolic engineering of Phaeodactylum tricornutum for the enhanced accumulation of omega-3 long chain polyunsaturated fatty acids. Metab Eng 2014, 22:3-9.

24. Shiran D, Khozin I, Heimer YM, Cohen Z: Biosynthesis of eicosapentaenoic acid in the microalga Porphyridium cruentum. I: The use of externally supplied fatty acids. Lipids 1996, 31:1277-1282.

25. Pohl P, Zurheide F: Fat production in freshwater and marine algae. In Marine Algae in Pharmaceutical Science, Volume 2. 2nd edition. Edited by Hoppe HA, Levring T. New York \& Berlin: W. de Gruyter; 1982:65-80.

26. Watanabe T, Kitajima C, Fujita S: Nutritional values of live organisms used in Japan for mass propagation of fish: a review. Aquaculture 1983, 34:115-143.

27. Mikhailova MV, Bemis DL, Wise ML, Gerwick WH, Norris JN, Jacobs RS: Structure and biosynthesis of novel conjugated polyene fatty acids from the marine green alga Anadyomene stellata. Lipids 1995, 30:583-589.

28. Sicko-Goad L, Ladewski BG, Lazinsky D: Synergistic effects of nutrients and lead on the quantitative ultrastructure of Cyclotella (Bacillariophyceae). Arch Environ Contam Toxicol 1986, 15:291-300.
29. Sicko-Goad L, Simmons MS, Lazinsky D, Hall J: Effect of light cycle on diatom fatty acid composition and quantitative morphology. J Phycol 1988, 24:1-7.

30. Ribier J, Patillon M, Falxa M-J, Godineau J-C: The antarctic diatom: Stellarima microtrias (Ehrenberg) Hasle \& Sims cell structure and vegetative cell enlargement in culture. Polar Biol 1988, 8:447-455.

31. Bayraktaroğlu E, Legovic T, Velasquez ZR, Cruzado A: Diatom Thalassiosira weissflogii in oligotrophic versus eutrophic culture: models and ultrastructure. Ecol Model 2003, 170:237-243.

32. Chiovitti A, Molino P, Crawford SA, Teng R, Spurck T, Wetherbee R: The glucans extracted with warm water from diatoms are mainly derived from intracellular chrysolaminaran and not extracellular polysaccharides. Eur J Phycol 2004, 39:117-128.

33. Kaluzhnaya OV, Likhoshway $\mathrm{V}$ : Valve morphogenesis in an araphid diatom Synedra acus subsp. radians. Diatom Res 2007, 22:81-87.

34. Grachev MA, Denikina NN, Belikov SI, Likhoshvaĭ EV, Usol'tseva MV, Tikhonova IV, Adel'shin RV, Kler SA, Shcherbakova TA: Elements of the active center of silicic acid transport proteins in diatoms. Mol Biol (Moscow) 2000, 236:534-536.

35. Sherbakova TA, Masyukova YA, Safonova TA, Petrova DP, Vereshagin AL, Minaeva TV, Adelshin RV, Triboy TI, Stonik IV, Aizdaitcher NA, Kozlov MV Likhoshway YV, Grachev MA: Conserved motif CMLD in silicic acid transport proteins of diatoms. Mol Biol 2005, 39:269-280.

36. Petrova DP, Bedoshvili YD, Shelukhina IV, Samukov W, Korneva ES, Vereshagin AL, Popkova TP, Karpyshev NN, Lebedeva DV, Klimenkov IV, Likhoshway Y, Grachev MA: Detection of the silicic acid transport protein in the freshwater diatom Synedra acus by immunoblotting and immunoelectron microscopy. Dokl Biochem Biophys 2007, 417:295-298.

37. Bedoshvili YD, Popkova TP, Likhoshval YV: Chloroplast ultrastructure in some diatoms from different classes. Tsitologiia 2009, 51:346-357.

38. Ravin N, Galachyants YP, Mardanov AV, Beletsky AV, Petrova DP, Sherbakova TA, Zakharova YR, Likhoshway YV, Skryabin KG, Grachev MA: Complete sequence of the mitochondrial genome of a diatom alga Synedra acus and comparative analysis of diatom mitochondrial genomes. Curr Genet 2010, 56:215-223.

39. Vereshchagin AL, Glyzina OY, Basharina TN, Safonova TA, Latyshev NA, Liubochko SA, Korneva ES, Petrova DP, Annenkov W, Danilovtseva EN, Chebykin EP, Volokitina NA, Grachev MA: Culturing of a fresh-water diatom alga Synedra acus in a $100 \mathrm{~L}$ photobioreactor and analysis of the biomass composition. Biotekhnologia 2008, 4:55-63.

40. Greenspan P, Mayer EP, Fowler SD: Nile red: a selective fluorescent stain for intracellular lipid droplets. J Cell Biol 1985, 100:965-973.

41. Takahashi E, Ledauphin J, Goux D, Orvain F: Optimizing extraction of extracellular polymeric substances (EPS) from benthic diatoms: comparison of the efficiency of six EPS extraction methods. Mar Fresh Res 2009, 60:1201-1210.

42. Dunstan GA, Volkman JK, Barrett SM, Leroi J-M, Jeffrey SW: Essential polyunsaturated fatty acids from 14 species of diatom (Bacillariophyceae). Phytochemistry 1994, 35:155-161.

43. Pahl SL, Lewis DM, Chen F, King KD: Heterotrophic growth and nutritional aspects of the diatom Cyclotella cryptica (Bacillariophyceae): effect of some environmental factors. J Biosci Bioeng 2010, 109:235-239.

44. Waller RF, Keeling PJ, Donald RGK, Striepen B, Handman E, Lang-Unnasch N, Cowman AF, Besra GS, Roos DS, McFadden Gl: Nuclear-encoded proteins target to the plastid in Toxoplasma gondii and Plasmodium falciparum. Proc Natl Acad Sci U S A 1998, 95:12352-12357.

45. Armbrust EV, Berges JA, Bowler C, Green BR, Martinez D, Putnam NH, Zhou S, Allen AE, Apt KE, Bechner M, Brzezinski MA, Chaal BK, Chiovitti A, Davis AK, Demarest MS, Detter CJ, Glavina T, Goodstein D, Hadi MZ, Hellsten U, Hildebrand M, Jenkins BD, Jurka J, Kapitonov W, Kröger N, Lau WWY, Lane TW, Larimer FW, Lippmeier JC, Lucas S, et al: The genome of the diatom Thalassiosira pseudonana: Ecology, evolution, and metabolism. Science 2004, 306:79-86.

46. Taguchi S, Hirata JA, Laws EA: Silicate deficiency and lipid synthesis of marine diatoms. J Phycol 1987, 23:260-267.

47. Wang H, Fu R, Pei G: A study on lipid production of the mixotrophic microalgae Phaeodactylum tricornutum on various carbon sources. Afr J Microbiol Res 2012, 6:1041-1047.

48. Popovich CA, Damiani C, Constenla D, Leonardi PI: Lipid quality of the diatoms Skeletonema costatum and Navicula gregaria from the South Atlantic Coast (Argentina): evaluation of its suitability as biodiesel feedstock. J Appl Phycol 2012, 24:1-10. 
49. Rojek A, Praetorius J, Frøkjaer J, Nielsen S, Fenton RA: A current view of the mammalian aquaglyceroporins. Annu Rev Physiol 2008, 70:301-327.

50. Meeuse BJD: Storage products. In Physiology and biochemistry of algae. Edited by Lewin RA. New York and London: Academic; 1962:293-299.

51. Alekseeva SA, Shevchenko NM, Kusaïkin MI, Ponomorenko LP, Isakov W, Zviagintseva TN, Likhoshvai EV: Polysaccharides of diatoms occurring in Lake Baikal. Prikl Biokhim Mikrobiol 2005, 41:213-219.

52. Shishlyannikov SM, Zakharova YR, Volokitina NA, Mikhailov IS, Petrova DP, Likhoshway Y: A procedure for establishing an axenic culture of the diatom Synedra acus subsp. radians (Kütz.) Skabitsch. from Lake Baikal. Limnol Oceanogr: Methods 2011, 9:478-484.

53. Thompson AS, Rhodes JC, Pettman I: Culture collection of algae and protozoa, catalogue of strains. Ambleside, Cumbria: Freshwater Biological Association; 1988.

54. Reynolds ES: The use of lead citrate at high pH as an electron-opaque stain in electron microscopy. J Cell Biol 1963, 17:208-212.

doi:10.1186/2241-5793-21-15

Cite this article as: Shishlyannikov et al:: Effect of mixotrophic growth on the ultrastructure and fatty acid composition of the diatom Synedra acus from Lake Baikal. Journal of Biological Research-Thessaloniki $201421: 15$

\section{Submit your next manuscript to BioMed Central and take full advantage of:}

- Convenient online submission

- Thorough peer review

- No space constraints or color figure charges

- Immediate publication on acceptance

- Inclusion in PubMed, CAS, Scopus and Google Scholar

- Research which is freely available for redistribution 